\title{
Selective Photoinduced Electron Transfer-Based Cyanoanthryl Fluorescent Chemosensors for Paramagnetic Metal Cations
}

\author{
Jeong Ho Chang, ${ }^{*}$ Yeonbwan Jeong, ${ }^{\dagger}$ and Young-Kook Shin ${ }^{\dagger}$ \\ Nanoceramics Center, Korea Institute of Ceramic Engineering and Technologi, Guemcheon-gu, Seoul 153-801, Korea \\ -Department of Chemistry, Chungbuk National Cniversitw. Cheongiu, Chunghuk $361-763$, Korea \\ Received September +2002
}

Key Words : Fluorescent quenching. Chemosensor. Photoinduced electron transfer. Stern-Volmer plot

The fluorescent chemosensor of fluorophore-space-receptor type requires the suppression of the interaction between the fluorophore and the quenching metal cations so as to observe fluorescence changes on the metal binding. The crown ethers have been derivatized with anthryl groups and different spacer units in the "fluorophore-space-receptor". These sy stemis have been designed to explore further understanding of PET process. The spacer units have been varied in order to observe the effect of spacer on the flexibility of the fluorophore unit with respect to the receptor moiety. the orientation of the fluorophores with respect to each other depending on the structure of spacer, and the interaction between the fluorophore and the receptor unit. Since Czarnik. $^{1}$ and de Silva ${ }^{2}$ successfully developed sensor systems to show chelation enhanced fluorescence (CHEF) and $C H E Q$ in the presence of metal guests using the anthryl polyaza receptors which complex the metal guests in its cavity leading to the suppression of the quenching interaction, the development of PET sensors has been focused only on the electron-delocalized antluracence fluorophore without consideration of electron-localized sy stem by electron donating or withdrawing functional group.

Here we report the preparation of PET-based cyanoantluryl fluorescent chemosensors (3. 4) for the paramagnetic metal guest. which was designed to explore the influence of the structural factor by electron withdrawing group, rigidity on the efficiency of the signaling mechanism, and the photophysical behavior (Scheme 1).

The cyanoanthryl fluorophores were synthesized via the synthesis of functionalized antluracene derivatives in introducing the azacromn ether substituents at 9-anthry lic position in order to generate the photoinduced electron transfer signal via the methylene $\left(-\mathrm{CH}_{2}\right)$ bridge from the electron donor to electron acceptor. The absorption and fluorescence spectra were measured for the synthesized cyanoanthryl fluorophores in methanol at $5 \times 10^{-7} \mathrm{M}$, excited by $254 \mathrm{ln}$. All santple solutions show a maxinum absorption at $25+\mathrm{nm}$, and a maximum emission at $426 \mathrm{~km}$. The maximum emission peaks of the $\pi-\pi^{*}$ transition show a red shift compare to those in antluyl derivatized fluorophores as shown in Figure 1. ${ }^{3}$ This shift of emission peak may be

\footnotetext{
${ }^{*}$ To whom correspondence should be addressed. E-mail: jhohang akicet.re kr; All authors contributed equally to this work.
}

attributed to some conjugative effect by the electron withdrawing property of cyano group.

The fluorescence quenching efficiency of cyanoantluryl fluorophores is dependent on the ring size and the number of donor atom in crown ethers as a receptor. The results indicate that signaling mechanism has to rely on long-range processes. which is quenched by the nonbonding electrons of benzylic nitrogen and oxygen atoms participating in nonradiative quenching process. Figure 2 shows the $\mathrm{pH}$ dependency of the fluorescence intensity of cyanoanthryl fluorophores at the $262 \mathrm{num}$ of excitation wavelength, showing a maximum at $\mathrm{pH} 3-5$ in Tris-buffer solution. This dependency can be explained by the intramolecular amine quenching mechanism that has been previously described. ${ }^{4}$ Protonation of amine group in antlurylic position results in the elimination of photoinduced electron transfer. The fact that two cyanoantluryl fluorophores show same maximum intensity at the same $\mathrm{pH}$ would be a major reason, indicationg the protonated species on the anthrylic nitrogen accounts for a majority of the observed intramolecular quenching. Also. this means that an electron transfer process from excited anthracene moiety to the partially positive charged amine take place, thus competing with radiative deactivation and partially quenching fluorescence. Fluorescence quenching is attributed to the interaction between the lone pair electron and $\pi$-orbital of the photo-induced antluracene fragment from the electron-rich anthrylic amine moiety in spacer unit to anthryl fluorophore.

In the lower $\mathrm{pH}$. the strong fluorescence intensity was observed reducing an electron withdrawing property of cyano group because of the formation of $-\mathrm{CNH}$ by protonation. But, the fluorescence intensity shows drastically quenching in ligher $\mathrm{pH}$ owing to the localization of electron density by cyano group and lone-pair electrons in receptor. Anong the 18 metal nitrates, which the fluorescence intensity of the cyanoantluryl fluorphores was measured for 0.1 . l. $10,1000 \mu \mathrm{M}$ of metal concentration at $\mathrm{pH} 9.2$, only four paramagnetic metal ions of $\mathrm{Mn}^{2-}(d \dot{f}) \cdot \mathrm{Fe}^{3+}(d \dot{f}) \cdot \mathrm{Co}^{3+}\left(d^{j}\right)$. and $\mathrm{Cu}^{2+}\left(d^{2}\right)$ quenched the fluorescence drastically at higher concentration. Figure 3 shows the fluorescence quenching curves depending on the metal concentration and a linear function of Stern-Volmer plots indicating that fluorescence quenching is dynamic in nature in the linear part. The degree of quenching shows an order of $\mathrm{Co}^{2+}>\mathrm{Cu}^{2+}>\mathrm{Mn}^{2-}>\mathrm{Fe}^{3-}$. 


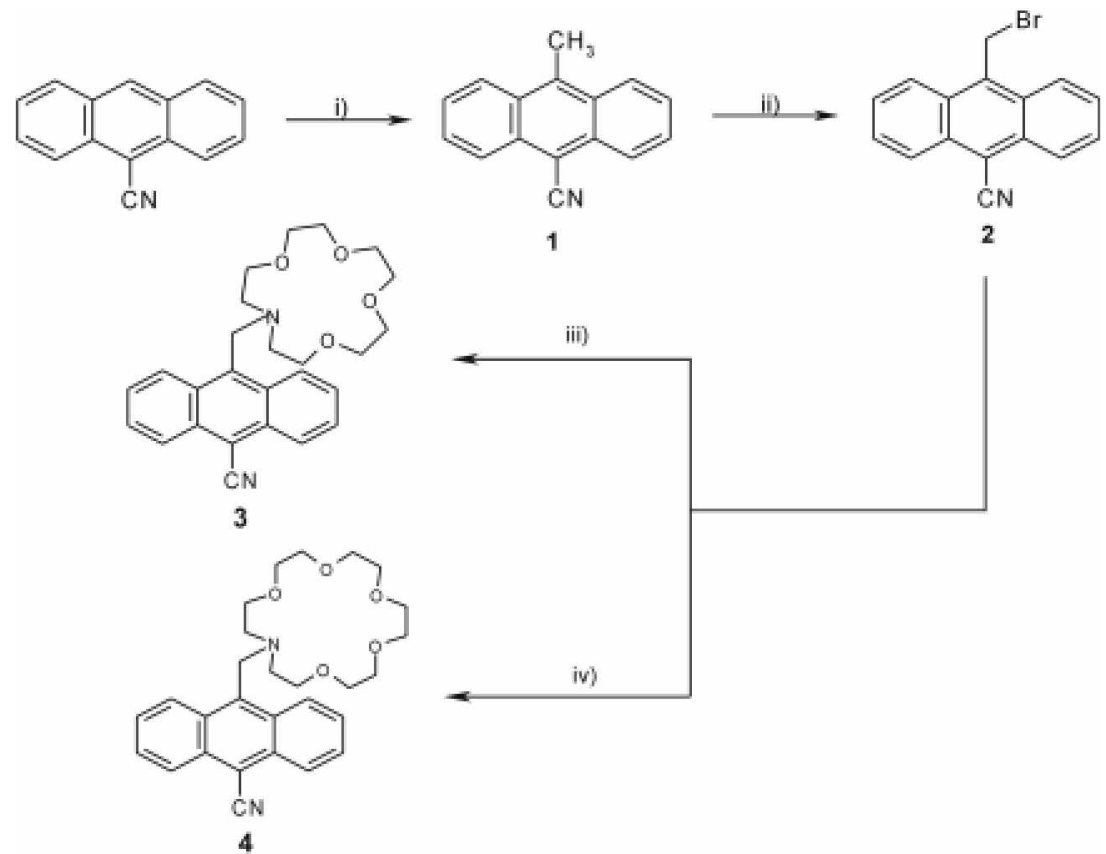

Scheme 1. (i) $\mathrm{f}$-BuOK, DMSO, $70^{\circ} \mathrm{C}, \mathrm{N}_{2}$, (ii) $\mathrm{NBS}, \mathrm{CCl}_{4}$, reflux for 24 hrs, $\mathrm{N}_{2}$, (iii) MAl $5 \mathrm{C} 5$, TEA, berlzene, reflux for 72 hrs, $\mathrm{N}_{2}$, and (iv) MA18C6, TEA, benzene, reflux for $72 \mathrm{hrs}, \mathrm{N}_{2}$.

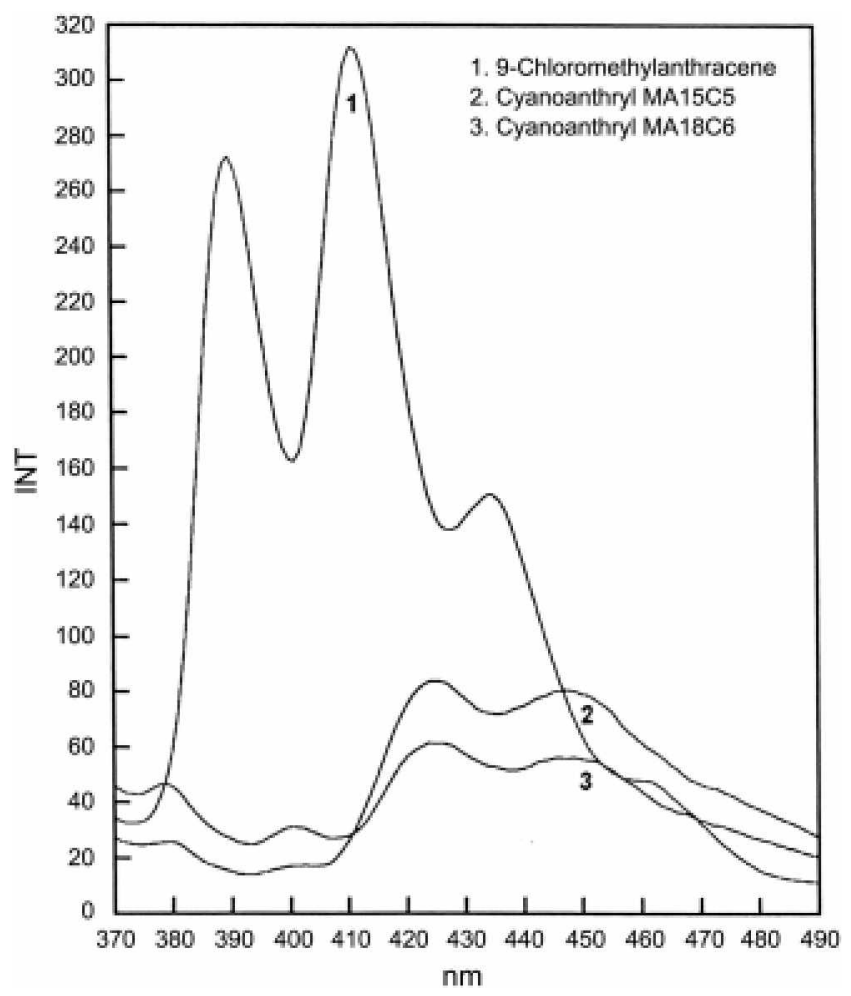

Figure 1. The comparison of the emission spectra of Chloromethyl antluacene (1), Cyanoanthryl MAljC5 (2), and Cyanoanthryl $\mathrm{MA} 18 \mathrm{C} 6$ (3) in $\mathrm{MeOH}$.

This result can be explained by the paramagnetic properties of metal ions. all having the unpaired $d$ electrons. which can be effectively quenched both singlets and triplets of cyanoanthryl fluorophore. Especially. $\mathrm{Cu}^{2+} . \mathrm{Mn}^{2-}, \mathrm{Fe}^{3-}$ are weaker quencher than $\mathrm{Co}^{2-}$ because of stability of the half-

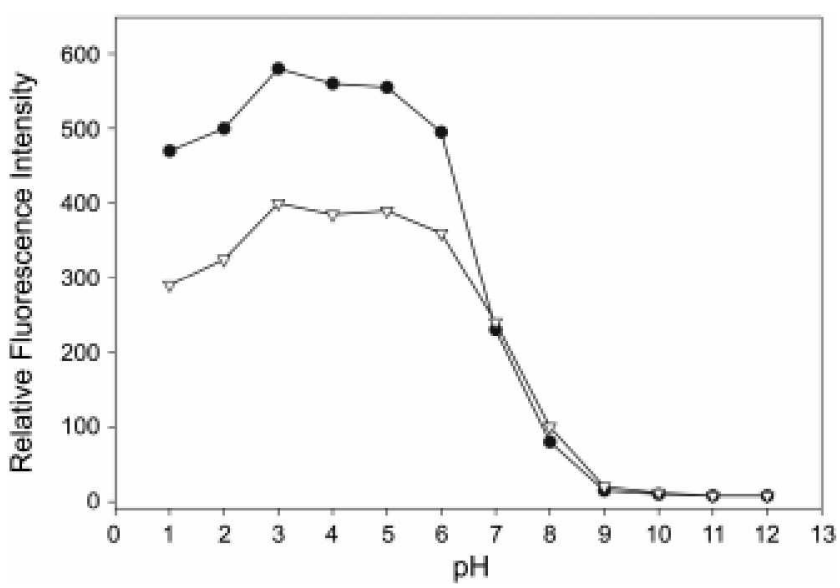

Figure 2. The pH-fluorescence profiles for $0.1 \mu \mathrm{M}$ of cyanoanthryl fluorophores. Emission was measured at the emission maximum centered near $426 \mathrm{~mm}$. : Cyano anthryl MAl5C5, and $\nabla$ : Cyanoanthryl MA18C6)

filled shell of $d^{6}$-metal ion $\left(\mathrm{Mn}^{2-}, \mathrm{Fe}^{3-}\right)$ and the existence of only one unpaired electrons of $\mathrm{Cu}^{2+}$. The quenching constants $s^{i}$ were calculated from the Stern-Volmer plot to elucidate a quenching degree as following: Cyanoanthryl MAl5C5: $4.91>4.62>4.55>4.31$ and Cyanoanthryl MAl8C6: $4.92>4.67>4.64>4.46$ for $\mathrm{Co}^{2+}$. $\mathrm{Cu}^{2+} . \mathrm{Mn}^{2-}$. and $\mathrm{Fe}^{3-}$. respectively.

To determine the static or dynamic quenching without measurement of fluorescence lifetime. ${ }^{7}$ the absorption spectra were measured carefully to distinguish the static or dynamic quenching. There is no change in the absorption spectra because the dynamic quenching only affects the excited states of the fluorophores. We found that the measured absorption spectra were not influenced by the metal ions as 

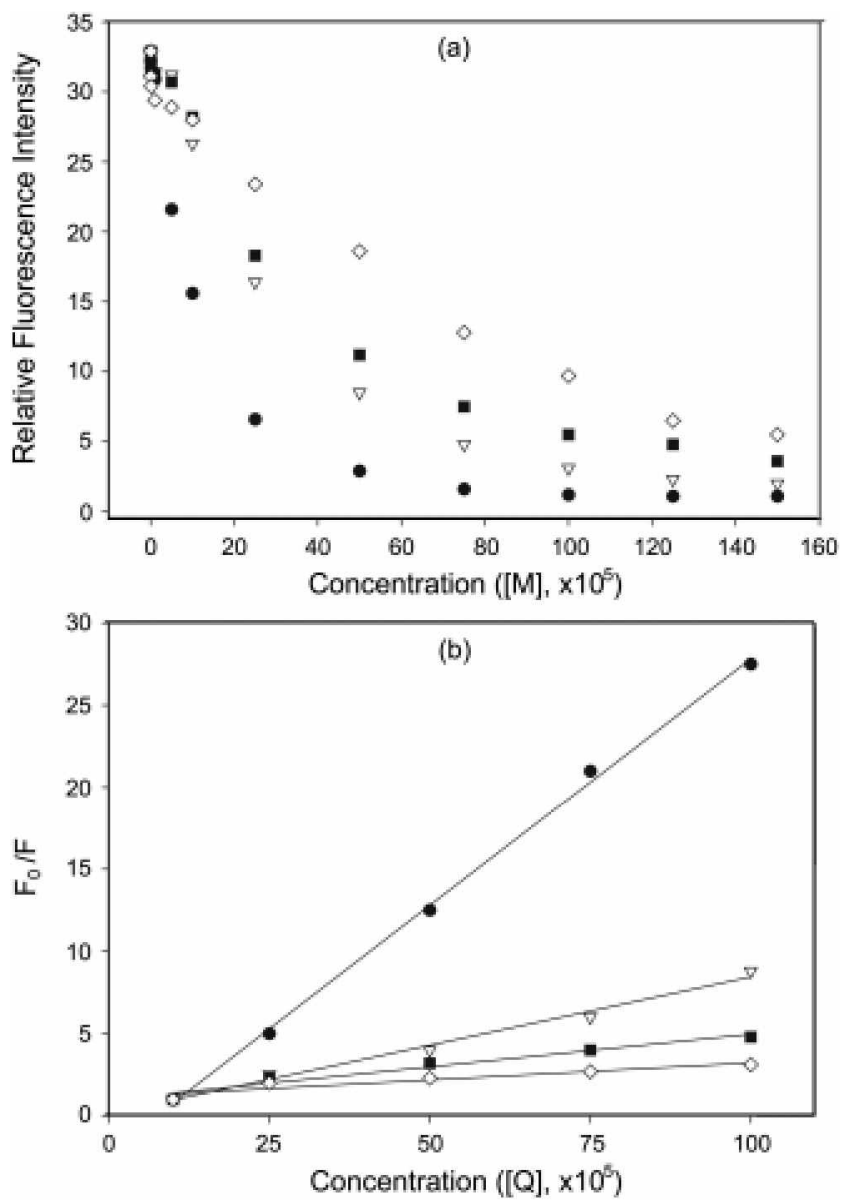

Figure 3. (a) Quenched fluorescence intensity dependent on the metal concentration, and (b) Stem-Volmer plots for Cvanoanthryl $\mathrm{MA} 15 \mathrm{C} 5 \cdot\left(\bullet: \mathrm{Co}^{2+}, \nabla: \mathrm{Cu}^{2+}, \mathbf{\square}: \mathrm{Mn}^{2-}\right.$, and $\left.: \mathrm{Fe}^{3+}\right)$

shown in Figure 4.

In conclusion, the PET-based cyanoanthryl fluorescent chemosensors were synthesized to demonstrate an electronic effect in the electron-localized fluorophores and showed a chelation enhanced fluorescence quenching by paramagnetic metal ions. Based on the Stern-Volmer plot. quenching constant for the complexation with each metal ion was calculated. and their CHEQ mechanism is dy'namic collision quenching process.

Synthesis of Fluorescent Chemosensors $(3,4)$. 10-methyl9-cyanoantluracene (1) was obtained by extraction with chloroform after stirring for 3 hours at $70^{\circ} \mathrm{C}$ of $0.97 \mathrm{~g}(4.77$ mmol) of 9-cyanoanthracene and $3 \mathrm{~g}(26.7 \mathrm{mmol})$ of $t$ BuOK in DMSO solution. The yield is $56 \%$ : ${ }^{1} \mathrm{H}-\mathrm{NMR}$ $\left(\mathrm{CDCl}_{\hat{\mathrm{j}}}\right.$. TMS $) \delta$ ppm: 3.12 (s. $\left.\mathrm{CH}_{3}\right) .7 .8-8.6\left(\mathrm{~m}_{2}, \mathrm{ArH}_{2}\right)$ : Mass $\mathrm{m} / \mathrm{z} 217\left(\mathrm{M}^{-}\right)$. 10-bromomethyy-9-cyanoantluracene (2) was obtained by recrystallization with hexane and chloroform mixture after refluxing for 24 hours of $1 \mathrm{~g}(4.92 \mathrm{mmol})$ of 10 -methyl-9-cyanoanthracene and $0.878 \mathrm{~g}(4.93 \mathrm{mmol})$ of $\mathrm{N}$-bromosuccinic acid (NBS): The yield is $34 \%$ and $\mathrm{m} . \mathrm{p}$ 200-202 ${ }^{\circ} \mathrm{C}:{ }^{1} \mathrm{H}-\mathrm{NMR}\left(\mathrm{CDCl}_{3}\right.$. TMS) $\delta \mathrm{ppm}: 5.5\left(\mathrm{~s} . \mathrm{CH}_{2} \mathrm{Br}\right)$. 7.8-8.6 (m. ArH): Mass m/z 296 (M). Cyanoanthryl MA15C5 (3) was obtained by column chromatography (2:1 of EtOAc/hexane) after refluxing the mixture of $0.110 \mathrm{~g}(0.5$

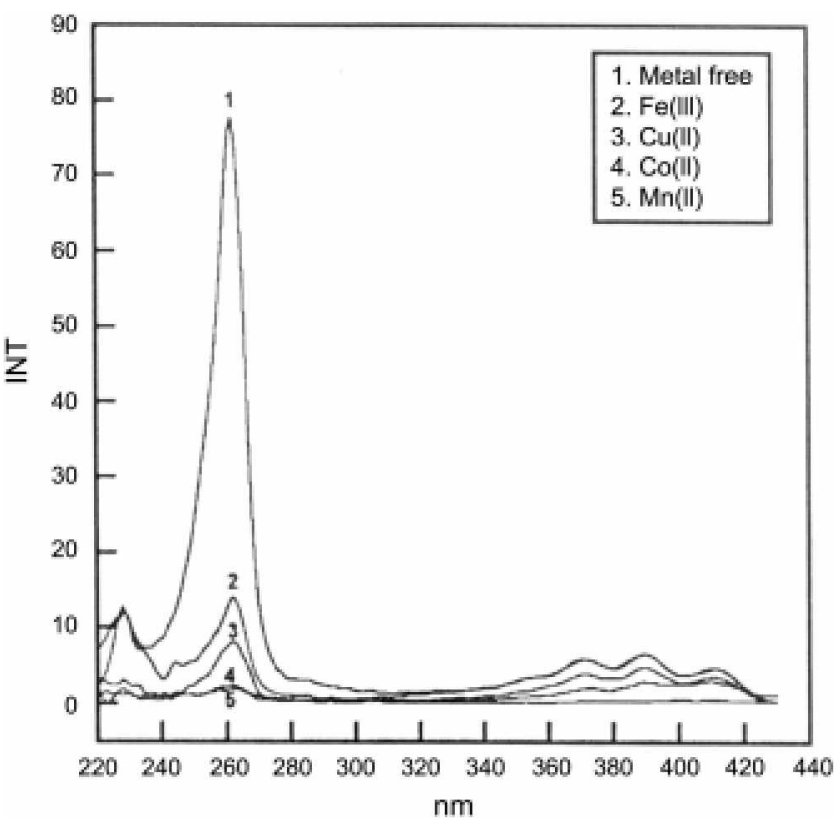

Figure 4. The absorption spectra in the absence and presence of the metal ions for Cyanoanthry MA $15 \mathrm{C} 5$.

mmol) of MAL 5 C 5 in benzene $(15 \mathrm{~mL}), 0.030 \mathrm{~g}(0.1 \mathrm{mmol})$ of 10-bromomethyl-9-cyanoantluracene and triethylamine $(0.44 \mathrm{~mL})$ in benzene $(15 \mathrm{~mL})$ under nitrogen atmosphere for 72 hours. The reaction mixture was cooled. filtered, and extracted with water. The organic layer was separated and concentrated in vacumm. Column cluromatography gave 36 $\%$ as a yellow solid; m.p $110-113{ }^{\circ} \mathrm{C} ;{ }^{1} \mathrm{H}-\mathrm{NMR}(\mathrm{CDCl}$, TMS) $\delta$ ppm: $2.9\left(\mathrm{~s} . \mathrm{NCH}_{3}\right), 3.6-3.8\left(\mathrm{~m}_{0}, \mathrm{OCH}_{3}\right), 4.8(\mathrm{~s}$, $\left.\mathrm{ArCH}_{2}\right)$, 6.5-8.7 (m. ArH): Mass $\mathrm{m} / \mathrm{z} 434\left(\mathrm{M}^{+}\right)$. Cyanoantluryl DA18C6 (4) was obtained by the same synthetic procedure of (3). Column chromatography gave $38 \%$ as a yellow solid: m.p $98-100{ }^{\circ} \mathrm{C}:{ }^{1} \mathrm{H}-\mathrm{NMR}\left(\mathrm{CDCl}_{3}\right.$. TMS) $\delta$ ppm: $2.9\left(\mathrm{~s}, \mathrm{NCH}_{2}\right), 3.6-3.8\left(\mathrm{~m} . \mathrm{OCH}_{2}\right) .4 .8\left(\mathrm{~s}, \mathrm{ArCH}_{2}\right), 6.5-$ 8.7 (m. ArH); Mass $\mathrm{m} / \mathrm{z} 478\left(\mathrm{M}^{-}\right)$.

\section{References}

1. (a) Czarnik, A. W. Acc. Chem. Res. 1994. 27.302-308. (b) Alkiaya, E. U.: Huston. M. E.: Czartik. A. W. J. Am. Chem. Soc 1990. 112. 3590-3593. (c) van Arman. S. A.: Czarnik. A. W. J. Ant. Chent. Soc. 1990. 112.5376-5377. (d) Huston. M. E.: Czarnik. A. W. J.Am. Chem. Soc 1990, 112. 7054-7056.

2. (a) de Silva, A. P.: Gunarante. H. Q. N.: McVeigh. C.: Maguire. G E.: Maxwell, P. R. S.; OHanlon, E. Chem Commo 1996. 2191 2192. (b) de Silva. A. P.: Gunarante. H. Q. N.: Habib-Iiwan. T. L.: McCoy. C. P.: Rice. T. E.: Soumilion. T. P. Angew. Chem. Int Ed. Engl. 1995. 34. 1728-1731. (c) de Silva. A. P.: Gunarante. H. Q. N.) Rice, T. E. Angew Chent. Iht. Ed. Engl 1996. 31,2116-2118.

3. (a) Chang. J. H. Kim, H. J.: Park. J. H.; Shin, Y. K; Chung, Y. Bull. Korean Chem Soc 1999. 20. 796-800. (b) Chang, J. H. Choi. Y. M.: Shit]. Y. K. Bull. Korean Chem. Soc. 2001. 22. 527530 .

4. (a) Horiguchi. E.: Shirai. K.: Matsuok. M.: Matsui. M. Dres Pigntents. 2002, 53. 45-55. (b) Horiguchi, E.: Shirai, K.: Jaung, J.; Furusyo. M: Takagi, K.: Matsuok, M. Dyes Pignents. 2001. 50. 99-103. (c) Shirai, K.: Matsuok. M: Futunish, K. Dues Pigments. 1999. $42.95-101$. 
5. (a) Fabbrizzi. L: Licchelli. M: Pallavicini, P.: Perotti, A: Taglietti. A.: Sacchi. D. Chem. Ew: J. 1996. 2. 75-82. (b) Unob. F.: Astari. Z.: Vicens. J. Tetrahedron Lett. 1998. 39. 2951-2954

6. The quenching constant was obtained by the plot of $F_{0} F$ versus $[Q]$ from the following equation: $F_{0} F=1+K_{0}[Q]$. where. $F_{0}: F$ is the ratio of fluorescence intensity in the absence and presence of quencher. and $[\mathrm{Q}]$ is the concentration of quencher.

7. (a) Lakowicz. A. R. Principles of Fluorescence Spectroscopy. Plenum: New York. 1983. (b) Ramachandram. B.: Samanta. A Chent. Phys. Lett. 1998. 290. 9-16. (c) Marek. M.: Bogndan. T. Chent. Phis Lett. 1999. 304, 309-316. 